\title{
Sorption of Copper(II) and Silver(I) by Four Bacterial Exopolysaccharides
}

\author{
M. Deschatre ${ }^{1,2, *}$, F. Ghillebaert ${ }^{3}$, J. Guezennec ${ }^{4}$, C. Simon Colin ${ }^{2}$
}

\author{
${ }^{1}$ Mexel Industries SAS, Route de Compiègne, 60410, Verberie, France \\ 2 Institut Français de Recherche pour l'Exploitation de la Mer, RBM/BMM, Centre de Brest, Pointe du Diable, \\ 29280, Plouzané, France \\ ${ }^{3}$ Ecotox, 11 rue Principale, 62380, Affringues, France \\ ${ }^{4}$ AiMB: Advices in Marine Biotechnology, 29280, Plouzané, France \\ *: Corresponding author : M. Deschatre, email address : $\underline{\text { mdeschat@ifremer.fr }}$
}

\begin{abstract}
:
Metal remediation was studied by the sorption of analytical grade copper $\mathrm{Cu}(\mathrm{II})$ and silver $\mathrm{Ag}(\mathrm{I})$ by four exopolysaccharides (EPS) produced by marine bacteria. Colorimetric analysis showed that these EPS were composed of neutral sugars, uronic acids (>20\%), acetate, and sulfate (29\%). Metal sorption experiments were conducted in batch process. Results showed that the maximum sorption capacities calculated according to Langmuir model were $400 \mathrm{mg} \mathrm{g}^{-1}$ EPS $\left(6.29 \mathrm{mmol} \mathrm{g}^{-1}\right)$ and $333 \mathrm{mg} \mathrm{g}^{-1}$ EPS $\left(3.09 \mathrm{mmol} \mathrm{g}^{-1}\right)$ for $\mathrm{Cu}(\mathrm{II})$ and $\mathrm{Ag}(\mathrm{I})$, respectively. Optimum $\mathrm{pH}$ values of $\mathrm{Ag}(\mathrm{I})$ sorption were determined as 5.7. Experiment results also demonstrated the influence of initial silver concentration and EPS concentrations. Microanalyzing coupled with scanning electron microscopy demonstrated the presence of metal and morphological changes of the EPS by the sorption of metallic cations. The Fourier transform infrared spectroscopy analysis indicated possible functional groups (e.g., carboxyl, hydroxyl, and sulfate) of EPS involved in the metal sorption processes. These results showed that EPS from marine bacteria are very promising for copper and silver remediation. Further development in dynamic and continuous process at the industrial scale will be established next.
\end{abstract}

Keywords: Sorption ; Bacterial exopolysaccharide ; Copper and silver removal ; Bioremediation 


\section{Introduction}

Heavy metals are being used widely, largely by industries (e.g., mining, electroplating, welding, electronic...). During the biogeochemical cycles of metals (1), the speciation of them and so their toxicity are modified. That is why, the release into the environment of even trace concentrations of heavy metals can cause severe aquatic or terrestrial damages $(2,3)$. In response to these issues, several methods exist to remove heavy metals from industrial effluents such as precipitation processes, electrochemical methods, sorption on activated carbon, membrane systems or chelating resins. However, these conventional methods are often expensive, inefficient and not safe (4).

In this context, sorption of heavy metals based on metal binding capacities of biological materials can be an alternative solution (5-7). Among numerous biosorbents (e.g., yeast, seaweed, bacteria, fungi), bacterial exopolysaccharides (EPS) have been effectively and successfully used in heavy metal removal studies (8-11). The advantage of microbial EPSs compared to plants, crustacea or algal polymers are related to their chemical and physical properties and their production that is less subjected to instability due to crop loss, marine pollution or climate change (12). Moreover, EPS have ionizable functional groups like carboxyl, acetate, hydroxyl, amine, phosphate and more rarely sulfate groups, which are potential binding sites for the sequestration of heavy metals (13). It is admitted that metal sorption implies a physico-chemical interaction between the metal cation and functional groups based on physical sorption, ion exchange, complexation and/or precipitation (14). Moreover, metal sorption performance also depends on external factors like $\mathrm{pH}$, metal concentration or biomass concentration.

Several studies on copper sorption by EPS have been carried out $(11,15)$, however none were performed on silver sorption by purified EPS. Copper and silver are largely used in a wide range of industrial applications (e.g. mining, electronic, water purification). Nevertheless, it is well known $(3,13,15)$ that both metals exhibit toxicity to aquatic life and constitute important risk for human health.

The aim of the present work was to determine the sorption capacity of four different bacterial exopolysaccharides that could be used as efficient biosorbents for the remediation of two heavy metals rejected by industrial activities, $\mathrm{Cu}$ (II) as a commonly studied cation and $\mathrm{Ag}$ (I) that has been very little studied. Moreover, importance of initial $\mathrm{pH}$, metal and sorbent concentration on the binding capacity of these metals were studied on one EPS.

\section{Materials and methods}

\subsection{Bacterial strains and EPS production}

Strains referenced as M1, M3 and M4 were isolated from different microbial mats in Rangiroa atoll (French Polynesia) and Tahiti Island $(16,17)$. EPS referenced as M2 was provided by Prof G.Geesey from Montana State University (USA). Bacterial production of exopolysaccharides along with the associated extraction and purification protocols have been previously described (17).

\subsection{Chemical characterization of EPS}

Global composition of EPS (neutral, uronic and hexosamine contents of the different exopolysaccharides) was determined using colorimetric methods, while monosaccharide 
composition and ratios were determined using GC analyses. Non carbohydrate substituents were determined by either HPLC and/or NMR analyses. These chemical EPS's analyses were described in previous works $(18,19)$. The molecular weight of EPS was determined by high-performance size-exclusion chromatography (HPSEC) and the polydispersityindex (Ip) was calculated from the Mw/Mn ratio (University Le Mans UMR $6120 \mathrm{PCl}$ ).

\subsection{Chemicals}

All chemicals used in this study were of analytical grade. Stock solutions of $\mathrm{Cu}$ (II) $(1000 \mathrm{mg}$ $\left.\mathrm{L}^{-1}\right)$ were prepared by dissolving $\left(\mathrm{Cu}\left(\mathrm{COOCH}_{3}\right)_{2}\right)$ from Merck in ultrapure water and stock solutions of $\mathrm{Ag}(\mathrm{I})\left(500 \mathrm{mg} \mathrm{L}^{-1}\right)$ were prepared by dissolving (AgNO3) from Sigma Aldrich in ultrapure water.

\subsection{Metal sorption experiments}

The sorption experiments were performed in a flask by dissolving $50 \mathrm{mg}$ of the dry EPS in $100 \mathrm{ml}$ of the metal solution at initial concentrations in the range of $100-1000 \mathrm{mg}^{-1}$ for $\mathrm{Cu}$ (II) and 50-500 mg. $\mathrm{L}^{-1} 20$ for $\mathrm{Ag}(\mathrm{I})$, as described previously $(3,6,7,8)$. Silver experiments were performed in the dark due to the photosensibility of silver nitrate. Solutions were prepared in triplicate and were gently shaken for one night, as determined in preliminary experiments showing equilibrium was reached in a few minutes to a few hours. All along the experiment, $\mathrm{pH}$ was regularly checked. At the end of each experiment, the solutions were ultrafiltered using Pellicon ${ }^{\circledR}$ Tangential Flow Filtration Cassettes with a nominal molecular weight cutoff of $100 \mathrm{kDa}$ to eliminate all free metal ions remaining in the solution. Permeates were used to determine concentrations of each metal cations whereas retentates were lyophilized prior to further analysis.

Appropriate controls were analysed during the sorption experiments to check the absence of glassware sorption of metals and other potential side effects.

The amount of metal ions sorbed at equilibrium per unit mass of EPS was defined using the general equation :

$$
q=\frac{(C i-C e q) \cdot V}{m}
$$

where $q$ is the metal uptake at equilibrium, in mg metal. $\mathrm{g}^{-1}$ of the biosorbent. $\mathrm{Ci}$ is the initial metal concentration and $\mathrm{Ceq}$ the equilibrium metal concentration in solution $\left(\mathrm{mg} \cdot \mathrm{L}^{-1}\right)$ of volume $V(\mathrm{~mL})$ and $\mathrm{m}$ the mass of EPS $(\mathrm{mg})$.

Additional sorption experiments at different $\mathrm{pH}$ values were conducted with the EPS M1 (50 $\left.\mathrm{mg} \mathrm{Ag}{ }^{+} \cdot \mathrm{L}^{-1}\right)$. $\mathrm{pH}$ of the solution was adjusted to $2,4,5,6$ and 8 by using either $0.1 \mathrm{M} \mathrm{NaOH}$ or $0.1 \mathrm{M} \mathrm{HCl}$. pH of the tested solutions was checked using $\mathrm{pH}$ meter ( $\mathrm{pH} 197 \mathrm{i}, \mathrm{WTW})$ at regular intervals, and adjusted to the initial $\mathrm{pH}$ value. Moreover, experiments using different EPS concentrations $\left(10,50,100,250\right.$ and $\left.500 \mathrm{mg} . \mathrm{L}^{-1}\right)$ were performed to evaluate the optimal silver uptake.

\subsection{Equilibrium sorption isotherm}

$\mathrm{Cu}$ and Ag uptakes were plotted according to the linearized model of Langmuir (20). This classical isotherm can be simply expressed by the following equation:

$$
q=\frac{Q \max \cdot K \cdot[\mathrm{Me}] e q}{1+K \cdot[\mathrm{Me}] e q}(1)
$$


where Qmax $\left(\mathrm{mg}^{-1} \mathrm{~g}^{-1}\right)$ represents the maximum sorption capacity, $K$ is the Langmuir equilibrium constant $\left(\mathrm{L} . \mathrm{mg}^{-1}\right)$ and $[\mathrm{Me}]$ eq $\left(\mathrm{mg} \cdot \mathrm{L}^{-1}\right)$ the equilibrium concentration of the metal in the solution. Linear transformation of equation (1) enables the calculation of the Langmuir's parameters.

Furthermore, thermodynamic considerations of a sorption process are necessary to conclude if the process is spontaneous or not (21). The standard Gibbs free energy change $\left(\Delta G^{\circ}\right)$ can be calculated by using the following equation: $\Delta G^{\circ}=-R T$ In $K$ were $R$ is universal gas constant (8.314 $\left.\mathrm{J} \mathrm{mol}^{-1} \mathrm{~K}^{-1}\right)$ and $\mathrm{T}$ is the absolute temperature (in $\mathrm{K}$ ). $\Delta G^{\circ}$ is an indication of spontaneity of a chemical reaction at a given temperature.

\subsection{Metal Analysis}

After ultrafiltration, permeates were acidified with $\mathrm{HNO} 3(0.5 \mathrm{~N})$ and the metal concentration was determined by Inductive Coupled Plasma-Atomic Emission Spectroscopy analysis (ICPAES, HORIBA Jobin YVON ULTIMA 2). The ICP analyses were conducted at wavelengths of $324.754 \mathrm{~nm}$ and $328.068 \mathrm{~nm}$ for copper and silver, respectively. All assays were run in triplicate.

\subsection{Scanning electron microscopy}

Freeze dried EPS samples were pasted to aluminium stubs. Samples were coated with gold with a sputter coater and finally observed with a Quanta 200 (FEI) scanning electron microscope coupled with an Energy-dispersive X-ray spectroscopy (EDS, Oxford).

\subsection{Fourier Transformed InfraRed spectroscopy}

FTIR spectra of dried EPS were recorded on Thermo scientific Nicolet iS10 FTIR spectrometer, equipped with a Universal ATR (attenuated total reflectance) sampling device containing diamond/ZnSe crystal. Spectra were scanned at room temperature in transmission mode over the wave number range of $4000-600 \mathrm{~cm}^{-1}$, with a resolution of 4 $\mathrm{cm}^{-1}$.

\subsection{Statistics}

Statistical analysis were performed using xlstat software (AddinsoftTM version 2012.6.04). The results were evaluated for normality and homogeneity of variances. If the assumptions of normality and homogeneity of variances were not met, homogenisation of variances were performed using the Box-cox transformation Then, ANOVA, Dunnett's and Tukey's procedures were used to evaluate the data.

\section{Results and Discussion}

\subsection{Chemical composition of EPS}

Selected polysaccharides were characterized by percentages of neutral sugars, uronic acids, hexosamines, sulfates and other substituents (Table 1).

With the exception of EPS M4, the chemical composition indicated high percentage of neutral sugars (>46\%, Table 1). Moreover, uronic acids accounted for 8 to $27 \%$ (except M2) thus contributing to their anionic character (22-24). EPS referenced as M2 was mainly composed of neutral sugars as glucose as previously determined and showed a high 
polydispersity index $(\mathrm{Ip}=4.2)$ reflecting the heterogeneity of polymer and a relatively low (870 kDa) molecular mass.

The chemical composition of M1 appeared to be different from the others due to its high sulfate content reaching $29 \%$. In the same way as carboxyl group (pKa $=4-5$ ) of uronic acid, the sulfonic group ( $\mathrm{pKa}=-2.6$ ) can be dissociated and display ionic interaction with metals. This polymer was also characterized by a high molecular weight $(4300 \mathrm{kDa})$ and a low Ip (1.3). EPS M3 showed high amounts of uronic acids amounts $(20 \%)$ and a high molecular weight $(1800 \mathrm{kDa})$ whereas EPS M4 was characterized by equal amounts of uronic acids and hexosamines. Moreover, the four polymers had a very low protein amount $(<5 \%)$ reflecting the efficiency of the purification protocol.

\subsection{Heavy metal sorption isotherms}

Sorption isotherms of $\mathrm{Cu}$ by the different EPS are shown in Fig. 1. Sorption isotherms represent the equilibrium of metal between the aqueous phase and the EPS versus metal concentration (9, 10). For EPS M1 (Fig. 1), sorption increased with the initial metal concentration. In that, it can be hypothesized that metal accumulation by this bacterial EPS is a chemical, equilibrated and saturated mechanism $(9,11)$. As listed in Table 2 , the maximum amount (Qmax, calculated from the Langmuir's equation) of $\mathrm{Cu}$ sorption was observed with EPS M1 with a huge Cu uptake capacity reaching $400 \mathrm{mg}$ Cu.g-1 EPS $\left(6.3 \mathrm{mmol} \mathrm{Cu.g}{ }^{-1}\right.$ EPS). The two others EPS (M3 and M4) showed interesting copper-binding capacities with $139 \mathrm{mg}$ Cu.g-1 EPS (1.29 mmol Cu.g-1 EPS) and $112 \mathrm{mg}$ Cu.g-1 EPS (1.77 mmol Cu.g ${ }^{-1}$ EPS), respectively. Neutral polymer M2 was unable to bind any copper ion. One can note that during metal sorption experiments, $\mathrm{pH}$ values remained steady, with no significant variation as shown in Table 4.

Silver sorption isotherms were obtained in the same way as copper and are shown in Fig. 2 . Experiments conducted with silver salts showed that all EPS were able to bind silver ions. The maximum amounts (Qmax) were observed with EPS M3 (333 mg Ag. ${ }^{-1}$ EPS ; 3.09

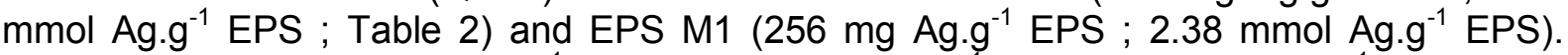
Binding capacities of $145 \mathrm{mg} \cdot \mathrm{g}^{-1}$ EPS (1.34 mmol Ag. $\mathrm{g}^{-1}$ EPS) and $100 \mathrm{mg} \cdot \mathrm{g}^{-1}$ EPS (3.15 mmol Ag. $\mathrm{g}^{-1}$ EPS ) were determined for EPS M2 and EPS M4, respectively. Moreover, the calculated $\Delta \mathrm{G}^{\circ}$ values were negative (Table 2) thus indicating that sorption of $\mathrm{Cu}(\mathrm{II})$ and $\mathrm{Ag}(\mathrm{I})$ on EPS were spontaneous under the experimental conditions.

From these results, it can be hypothesized that EPS composition affects its metal sorption capacities. Actually, Loaec et al. (10) showed that the chemical composition of exopolysaccharides from bacteria Alteromonas macleodii fijiensis subsp composed by neutral sugars, acids, amino sugars and other functions such as sulfate and pyruvate esters contributed to the uptake of metals. The authors also identified specific functional groups specifically involved in metal binding. However direct relation between sorption capacity and EPS sugar composition is quite difficult because sorption mechanism is also probably affected by a set of other characteristics including EPS configuration, structure, molecular weight, and rheological properties.

In the same way, comparison with binding data reported in the literature remains a difficult task because of the different methodologies and experimental conditions $(\mathrm{pH}$, temperature, ionic strength, ranges of concentration of metal used, anion of the salt, etc.) and the nature of sorbents used (25-27). Nevertheless uptake capacities of the four bacterial EPS for the removal of $\mathrm{Cu}(\mathrm{II})$ and $\mathrm{Ag}(\mathrm{I})$ were compared with those of other biosorbents reported in literature (Table 3). With the exception of a copper uptake up to $1602 \mathrm{mg} . \mathrm{g}-130$ EPS as observed for Paenibacillus polymyxa (28), data from the present study indicated higher uptake values. The value of Qmax for silver sorption was up to $333 \mathrm{mg}^{-1} \mathrm{~g}^{-1}$ EPS M3, and this 
value was much higher than the observed capacities for an EPS slime produced by Alcaligenes eutrophus (53) and other natural biomasses reported in the literature ranging between 41.8 and $98.7 \mathrm{mg} \cdot \mathrm{g}^{-1}$.

Moreover, one can note that due the ability of acetate to complex to $\mathrm{Cu}$, sample may likely also contain a ternary complex made of Cu-AcCOO/EPS (as it has already been described), thus affecting $\mathrm{Cu}$ sortion capacities of EPS.

\subsection{Factors affecting sorption}

It is now well accepted that metal sorption implies physico-chemical interactions between metallic ions and EPS, and that interactions could be influenced by external factors, such as $\mathrm{pH}$, EPS concentration, metal concentration $(5,29)$. In the present study, due to its high binding capacity as well as other parameters such as low viscosity and high yield of production, EPS M1 was selected to study the effects of varying experimental conditions $(\mathrm{pH}$, EPS concentration, initial metal concentrations) on its metal binding capacities for silver.

\subsection{Effect of pH on silver sorption}

The sorption was ranged between 22.6 and $51.2 \mathrm{mg} \cdot \mathrm{g}^{-1}$ for $\mathrm{pH}$ ranged between 2 and 8 inducing an increase of the binding capacity of $28.6 \mathrm{mg} \cdot \mathrm{g}^{-1}$. The increase was significant between $\mathrm{pH}=2$ and $\mathrm{pH}=4$ and then remained stable between $\mathrm{pH}=5$ and $\mathrm{pH}=8$ (Fig 3 ). Our results are in agreement with previous works that demonstrated a reduction of metals sorption with decreasing $\mathrm{pH}(30,31)$. This phenomenon can be explained by modification of metal speciation itself acting on solubility, complexation, redox reactions through metal recovery $(5,31)$ and the ionization state of the functional groups (e.g. carboxyl, sulfate, phosphate and amino groups). pH modifies the EPS notably by ionisation of carboxylate and sulfate groups that permit the EPS components to be effective scavengers of metal cations (32). But equally the presence of $\mathrm{H}+$ ions at low $\mathrm{pH}(\mathrm{pH}=2-4)$ that could compete with $\mathrm{Ag}+$ cations for sorption sites onto the system thus affected silver sorption (33). Actually, with an experimental $\mathrm{pH}$ value of 5 , sorption capacity of silver increased, compared to lower $\mathrm{pH}$ values. Binding sites (such as carboxyl groups, $\mathrm{pKa}=4-5$ ) are then dissociated and available for binding to metal cations. The competitive effect of protons for binding sites is, at $\mathrm{pH} 5$, much lower. At $\mathrm{pH}$ values above 5, binding capacity of $\mathrm{M} 1$ for $\mathrm{Ag}$ remained unchanged with a

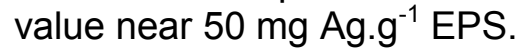

\subsection{Effect of EPS concentrations on silver sorption}

The effect of biosorbent concentration on the Ag+ sorption was determined at initial metal concentration of $50 \mathrm{mg} \mathrm{.I^{-1 }} \mathrm{Ag}(\mathrm{I})$ (Fig. 4). At equilibrium, the amount of $\mathrm{Ag}+$ sorbed onto the EPS M1 was found to decrease from 1055 to $56.2 \mathrm{mg}^{-1} \mathrm{~g}^{-1}$ with increasing the biosorbent concentration from 0.001 to $0.05 \%$. All values were significantly different from each others $(p$ $<0.05)$. The high EPS concentration could make a screening effect of the outer layer, thereby shielding the binding sites from metal (34).

\subsection{Effect of initial metal concentrations on metal sorption}

The effect of initial metal concentrations on $\mathrm{Cu} 2+$ and $\mathrm{Ag}+$ sorption by EPS M1 were determined with initial concentrations ranging from 50 to $500 \mathrm{mg} \cdot \mathrm{L}^{-1}$ for $\mathrm{Ag}(\mathrm{I})$ and from 100 to $1000 \mathrm{mg}^{-\mathrm{L}^{-1}}$ for $\mathrm{Cu}(\mathrm{II})$. Fig. 5 showed that both heavy metals exhibited the same behaviour. The sorption capacity (q) increased with increasing initial metal concentrations with a maximum sorption at $500 \mathrm{mg} \cdot \mathrm{L}^{-1}$ for $\mathrm{Ag}(\mathrm{I})$ and $900 \mathrm{mg} \cdot \mathrm{L}^{-1}$ for $\mathrm{Cu}(\mathrm{II})$. Globally, a rapid increase of sorption capacity in the area of low concentration was noted (Fig.5). Elevation of sorption capacity was observed with increasing initial metal concentration, thus indicating that strong interactions occurred between the available exchange surface of the EPS and the metal 
cations (Fig. 5). Then, a saturation was observed for higher metal concentrations $(\sim 300$ $\mathrm{mg} . \mathrm{L}^{-1}$ for $\mathrm{Ag}(\mathrm{I})$ and $\sim 700 \mathrm{mg} \cdot \mathrm{L}^{-1}$ for $\mathrm{Cu}(\mathrm{II})$ ), resulting from saturation of active sites involved in the sorption process (35).

\subsection{Morphological modifications of EPS induced by metal sorption observed by Scanning Electron Microscopy}

Morphology of EPS surface was observed by scanning electron microscopy before and after copper and silver sorption. This technique allows visualization of the presence or absence of metal in the sample (Fig. 6). In addition, micro analysis coupled with SEM allows characterization and quantification of EPS elemental constituents as well as metals sorbed onto the EPS. The SEM pictures confirmed the presence of metal and micro analysis (Fig. 6, $\mathrm{c}$ and $\mathrm{f}$, white arrows) indicated concentrations of metal ions up to $68 \%(\mathrm{w} / \mathrm{w})$ for copper and $\sim 30 \%(\mathrm{w} / \mathrm{w})$ for silver. In addition, these pictures showed morphology changes between native samples and those containing metal (Fig. 6). In particular, the presence of copper or silver on the EPS gave samples a smoother and less dentate (Fig. 6, b and d) aspect. Similar SEM observations were reported by other researchers,(36) with bacteria and (37) with green algae.

\subsection{Identification of EPS binding sites by Fourier Transformed InfraRed (FTIR) spectroscopy}

Infrared spectra of EPS M1 and EPS M3 before and after copper or silver binding are shown in Fig. 7 and in Fig. 8, respectively.

Comparison of FTIR spectra obtained for the Native EPS M1 and EPS M1 + Cu (Fig. 7) showed significant shifts. Significant differences were observed in stretching vibrations of hydroxyl groups around $3400 \mathrm{~cm}^{-1}\left(+71 \mathrm{~cm}^{-1}\right.$ compared to the native polysaccharide). Shifts were also noted for carboxyl stretching vibrations of $C=O$ at $1640 \mathrm{~cm}^{-1}\left(-6 \mathrm{~cm}^{-1}\right)$, that corresponds to uronic acids in the exopolymer. Some discrepancies were also noticed in the region of sulfate groups SO3 : at the band $1240 \mathrm{~cm}^{-1}\left(-6 \mathrm{~cm}^{-1}\right.$ compared to the native polysaccharide). EPS M1 is characterized by high amount of sulfate (28\%, Table 1$)$. Carboxyl or hydroxyl groups are known to be primarily involved in metal binding by forming coordination bonds that facilitate the stability of the complex $(11,38)$. According to FTIR analysis, these experiments support the assumption that sulfate groups seemed to be involved in the mechanisms of retention of copper despite the controversy on the role of sulfate in the metal-binding capacity of polysaccharides $(9,39)$. Sulfate groups are generally known to be involved in the overall uptake of trivalent ions, such as ferric ions (40). Confirmation of this could be done by complementary analysis by EXAFS spectroscopy.

In the same way as for copper, significant changes were observed on FTIR spectra of native EPS M3 and EPS M3 +Ag (Fig. 8). The most striking dissimilarity was again found in bands intensity of alcohol-OH groups around $3370 \mathrm{~cm}-1\left(-9 \mathrm{~cm}^{-1}\right.$ compared to the native EPS M3), as well as in vibrations of carboxylic acid groups ionized with a first band around $1600 \mathrm{~cm}-1$ $(-8 \mathrm{~cm}-1)$ of high intensity and a second band around $1400 \mathrm{~cm}^{-1}\left(-8 \mathrm{~cm}^{-1}\right)$. Differences were also located for stretching vibrations of primary C-OH to $1000-1080 \mathrm{~cm}^{-1}\left(-2 \mathrm{~cm}^{-1}\right)$ and secondary $\mathrm{C}-\mathrm{OH}$ between 1050 and $1160 \mathrm{~cm}^{-1}\left(-2 \mathrm{~cm}^{-1}\right)$. Our results are in agreement with previous studies, in particular those by Lin et al. (41), and Pethkar et al. (42) pointing out the role of both carboxyl and hydroxyl groups in sorption of silver in various biomasses.

\section{Conclusions}

In this study, we demonstrated the binding capacities of four bacterial EPS for $\mathrm{Ag}+$ and $\mathrm{Cu2+}$ heavy metals. Maximum uptake capacities as high as $400 \mathrm{mg}$ of $\mathrm{Cu}(\mathrm{II}) / \mathrm{g}$ and $333 \mathrm{mg}$ of $\mathrm{Ag}(\mathrm{I}) / \mathrm{g}$ were determined for two different EPS. Initial $\mathrm{pH}$, initial $\mathrm{Cu}(\mathrm{II})$ and $\mathrm{Ag}(\mathrm{I})$ concentration 
and initial EPS concentration highly affects the sorption of heavy metals. These results can be partly related to the specific chemical composition of EPS and the number of available binding sites. SEM analysis revealed morphological changes of the EPS before and after sorption of metallic cations. Fourier transformed infrared spectroscopy (FTIR) analysis indicated that major functional groups (carboxyl, hydroxyl and sulfates groups) on the EPS contribute to the uptake of the polysaccharide. These results showed that EPS from bacteria are very promising in terms of potential copper and silver remediation. With the view of industrial development of EPS-based metal remediation, studies dealing with immobilization of EPS onto regenerative matrix and further desorption of metal are in course in our laboratory. Further development in dynamic and continuous process at the industrial scale will be next established.

\section{Acknowledgments}

The authors extend their gratitude to Mexel Industries SAS for the financial support and Ifremer for the facilities. The authors are thankful to Prof G.Geesey for providing EPS M2. We also thank Mr N. Gayet from REM/EEP/LEP Ifremer Brest Center for his skilled assistance with SEM and Mrs C.Liorzou from UMR 6538 Domaines Océaniques IUEM for metal analysis on ICP AES. 
1. Gadd, G. M. (2004) Microbial influence on metal mobility and application for bioremediation,

Geoderma 122, 109-119.

2. Flemming, C. A., and Trevors, J. T. (1989) Copper toxicity and chemistry in the environment: a review, Water Air Soil Poll. 44, 143-158.

3. Ratte, H. T. (2009) Bioaccumulation and toxicity of silver compounds: A review, Environ. Toxicol. Chem. 18, 89-108.

4. Volesky, B. (2007) Biosorption and me, Water Res. 41, 4017-4029.

5. Gadd, G. M. (2009) Biosorption: critical review of scientific rationale, environmental importance and significance for pollution treatment, J. Chem. Technol. Biot. 84, 13-28.

6. Park, D., Yun, Y. S., and Park, J. M. (2010) The past, present, and future trends of biosorption,

Biotechnol. Bioprocess Eng. 15, 86-102.

7. Vieira, R. H. S. F., and Volesky, B. (2010) Biosorption: a solution to pollution?, Int. Microbiol. 3, 1724.

8. Comte, S., Guibaud, G., and Baudu, M. (2006) Biosorption properties of extracellular polymeric substances (EPS) resulting from activated sludge according to their type: Soluble or bound, Process Biochem. 41, 815-823.

9. Loaec, M., Olier, R., and Guezennec, J. (1998) Chelating properties of bacterial exopolysaccharides from deep-sea hydrothermal vents, Carbohyd. Polym. 35, 65-70.

10. Loaëc, M., Olier, R., and Guezennec, J. (1997) Uptake of lead, cadmium and zinc by a novel bacterial exopolysaccharide, Water Res. 31, 1171-1179.

11. Moppert, X., Le Costaouec, T., Raguenes, G., Courtois, A., Simon-Colin, C., Crassous, P., Costa, B., and Guezennec, J. (2009) Investigations into the uptake of copper, iron and selenium by a highly sulphated bacterial exopolysaccharide isolated from microbial mats, J. Ind. Microbiol. Biot. 36, 599604.

12. Guezennec, J. (2002) Deep-sea hydrothermal vents: A new source of innovative bacterial exopolysaccharides of biotechnological interest?, J Ind. Microbiol. Biot. 29, 204-208.

13. Liu, H., and Fang, H. H. P. (2002) Characterization of electrostatic binding sites of extracellular polymers by linear programming analysis of titration data, Biotechnol. Bioeng. 80, 806-811.

14. Gadd, G. M., and White, C. (1989) Uptake and intracellular compartmentation of thorium in Saccharomyces cerevisiae, Environ. Pollut. 61, 187-197.

15. De Philippis, R., Paperi, R., and Sili, C. (2007) Heavy metal sorption by released polysaccharides and whole cultures of two exopolysaccharide-producing cyanobacteria, Biodegradation 18, 181-187.

16. Guezennec, J., Moppert, X., Raguènes, G., Richert, L., Costa, B., and Simon-Colin, C. (2011) Microbial mats in French Polynesia and their biotechnological applications, Process Biochem. 46, 16-22.

17. Raguènes, G., Moppert, X., Richert, L., Ratiskol, J., Payri, C., Costa, B., and Guezennec, J. (2004) A novel exopolymer-producing bacterium, Paracoccus zeaxanthinifaciens subsp. payriae, isolated from a kopara mat located in Rangiroa, an atoll of French Polynesia, Curr. Microbiol. 49, 145-151. 
18. Guezennec, J. G., Pignet, P., Raguenès, G., Deslandes, E., Lijour, Y., and Gentric, E. (1994)

19. Lijour, Y., Gentric, E., Deslandes, E., and Guezennec, J. (1994) Estimation of the sulfate content of hydrothermal vent bacterial polysaccharides by Fourier transform infrared spectroscopy, Anal. Biochem. 220, 244-248.

20. Langmuir, I. (1918) The adsorption of gases on plane surfaces of glass, mica and platinum, J Am. Chem. Soc. 40, 1361-1403.

21. Aksu, Z. (2002) Determination of the equilibrium, kinetic and thermodynamic parameters of the batch biosorption of nickel (II) ions onto $<\mathrm{i}>$ Chlorella vulgaris $</ \mathrm{i}>$, Process Biochemistry 38, 89-99.

22. De Philippis, R., Sili, C., Paperi, R., and Vincenzini, M. (2001) Exopolysaccharide-producing cyanobacteria and their possible exploitation: a review, J Appl. Phycol. 13, 293-299.

23. Moreno, J., Vargas, M., Madiedo, J. M., Muñoz, J., Rivas, J., and Guerrero, M. G. (2000) Chemical and rheological properties of an extracellular polysaccharide produced by the cyanobacterium Anabaena sp. ATCC 33047, Biotechnol. Bioeng. 67, 283-290.

24. Shah, V., Ray, A., Garg, N., and Madamwar, D. (2000) Characterization of the extracellular polysaccharide produced by a marine cyanobacterium, Cyanothece sp. ATCC 51142, and its exploitation toward metal removal from solutions, Curr. Microbiol. 40, 274-278.

25. Guibaud, G., Tixier, N., Bouju, A., and Baudu, M. (2003) Relation between extracellular polymers' composition and its ability to complex $\mathrm{Cd}, \mathrm{Cu}$ and $\mathrm{Pb}$, Chemosphere 52, 1701-1710.

26. Pulsawat, W., Leksawasdi, N., Rogers, P. L., and Foster, L. J. R. (2003) Anions effects on biosorption of Mn (II) by extracellular polymeric substance (EPS) from Rhizobium etli, Biotechnol. Lett. 25, 1267 1270.

27. Paperi, R., Micheletti, E., and De Philippis, R. (2006) Optimization of copper sorbing-desorbing cycles with confined cultures of the exopolysaccharide-producing cyanobacterium Cyanospira capsulata, $J$ Appl. Microbiol. 101, 1351-1356.

28. Prado Acosta, M., Valdman, E., Leite, S. G. F., Battaglini, F., and Ruzal, S. M. (2005) Biosorption of copper by Paenibacillus polymyxa cells and their exopolysaccharide, World J. Microbiol. Biot. 21, 1157-1163.

29. Veglio, F., Beolchini, F., and Gasbarro, A. (1997) Biosorption of toxic metals: an equilibrium study using free cells of Arthrobacter sp, Process Biochem. 32, 99-105.

30. Donia, A. M., Atia, A. A., and Elwakeel, K. Z. (2007) Recovery of gold (III) and silver (I) on a chemically modified chitosan with magnetic properties, Hydrometallurgy 87, 197-206.

31. Esposito, A., Pagnanelli, F., and Veglio, F. (2002) pH-related equilibria models for biosorption in single metal systems, Chem. Eng. Sci. 57, 307-313.

32. Ozdemir, G., Ozturk, T., Ceyhan, N., Isler, R., and Cosar, T. (2003) Heavy metal biosorption by biomass of Ochrobactrum anthropi producing exopolysaccharide in activated sludge, Bioresource technology 90, 71-74.

33. Singleton, I., and Simmons, P. (1996) Factors affecting silver biosorption by an industrial strain of Saccharomyces cerevisiae, J Chem.Technol. Biot. 65, 21-28.

34. Pons, M. P., and Fuste, M. C. (1993) Uranium uptake by immobilized cells of Pseudomonas strain EPS 5028, Applied Microbiology and Biotechnology 39, 661-665.

35. Ozdemir, G., Ceyhan, N., and Manav, E. (2005) Utilization of an exopolysaccharide produced by Chryseomonas luteola TEM05 in alginate beads for adsorption of cadmium and cobalt ions, Bioresource Technol. 96, 1677-1682.

36. Sethuraman, P., and Balasubramanian, N. (2010) Removal of Cr (VI) from aqueous solution using Bacillus subtilis, Pseudomonas aeruginosa and Enterobacter cloacae, Int. J. Eng. Sci. Technol 2, 18111825 .

37. Onwuka, J. C., Ajibola, V. O., Kagbu, J. A., and Manji, A. J. (2011) Biosorption of Cr (VI) and Co (II) ions from Synthetic Wastewater using Dead Biomass of Fresh Water Green Algae Cosmarium panamense, Arch. Appl. Sci. Res. 3, 191-207.

38. Geddie, J. L., and Sutherland, I. W. (1993) Uptake of metals by bacterial polysaccharides, J. Appl. Microbiol. 74, 467-472.

39. Sheng, P. X., Ting, Y. P., Chen, J. P., and Hong, L. (2004) Sorption of lead, copper, cadmium, zinc, and nickel by marine algal biomass: characterization of biosorptive capacity and investigation of mechanisms, J Colloid Interf. Sci. 275, 131-141.

40. Figueira, M. M., Volesky, B., and Mathieu, H. J. (1999) Instrumental analysis study of iron species biosorption by Sargassum biomass, Environ. Sci. Technol. 33, 1840-1846.

41. Lin, Z., Zhou, C., Wu, J., Zhou, J., and Wang, L. (2005) A further insight into the mechanism of Ag+ biosorption by Lactobacillus sp. strain A09, Spectrochim. Acta A 61, 1195-1200. 
42. Pethkar, A. V., Kulkarni, S. K., and Paknikar, K. M. (2001) Comparative studies on metal biosorption by two strains of Cladosporium cladosporioides, Bioresource Technol. 80,211-215.

43. Morillo Pérez, J. A., Garcia-Ribera, R., Quesada, T., Aguilera, M., Ramos-Cormenzana, A., and Monteoliva-Sanchez, M. (2008) Biosorption of heavy metals by the exopolysaccharide produced by Paenibacillus jamilae, World J. Microbiol. Biot. 24, 2699-2704.

44. Norberg, A. B., and Persson, H. (1984) Accumulation of heavy metal ions by Zoogloea ramigera, Biotechnol. Bioeng. 26, 239-246.

45. Salehizadeh, H., and Shojaosadati, S. A. (2003) Removal of metal ions from aqueous solution by polysaccharide produced from Bacillus firmus, Water Res. 37, 4231-4235.

46. Grimm, A., Zanzi, R., Björnbom, E., and Cukierman, A. L. (2008) Comparison of different types of biomasses for copper biosorption, Bioresource Technol. 99, 2559-2565.

47. Padilha, F. P., de França, F. P., and da Costa, A. C. A. (2005) The use of waste biomass of Sargassum $s p$. for the biosorption of copper from simulated semiconductor effluents, Bioresource Technol. 96 , 1511-1517.

48. Mattuschka, B., and Straube, G. (1993) Biosorption of metals by a waste biomass, J Chem.Technol. Biot. 58, 57-63.

49. Dos Santos, V. C. G., De Souza, J. V. T. M., Tarley, C. R. T., Caetano, J., and Dragunski, D. C. (2010) Copper ions adsorption from aqueous medium using the biosorbent sugarcane bagasse in natura and chemically modified, Water Air Soil Poll., 1-9.

50. Akthar, N., Sastry, S., and Mohan, M. (1995) Biosorption of silver ions by processed Aspergillus niger biomass, Biotechnol. Lett. 17, 551-556.

51. Cordery, J., Wills, A. J., Atkinson, K., and Wills, B. A. (1994) Extraction and recovery of silver from low-grade liquors using microalgae, Miner. Eng. 7, 1003-1015.

52. Merroun, M. L., Omar, N. B., Alonso, E., Arias, J. M., and Gonzalez-Munoz, M. T. (2001) Silver sorption to Myxococcus xanthus biomass, Geomicrobiol. J. 18, 183-192.

53. Tsezos, M., Remoudaki, E., and Angelatou, V. (1995) A systematic study on equilibrium and kinetics of biosorptive accumulation. The case of $\mathrm{Ag}$ and $\mathrm{Ni}$, Int. Biodeter. Biodegr. 35, 129-153. 


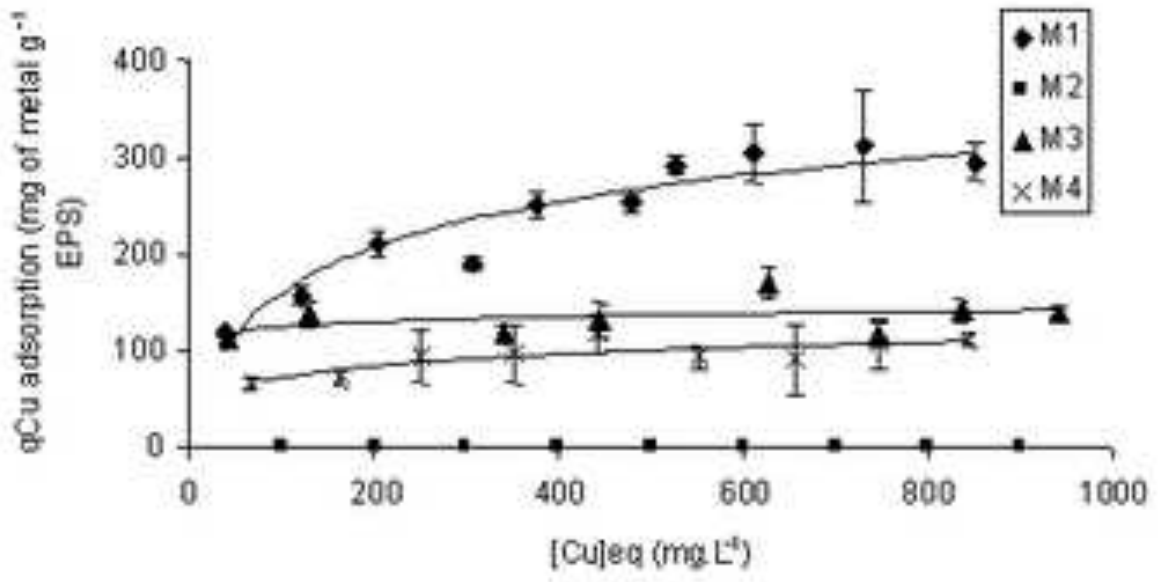


Figure 2

Click here to download high resolution image

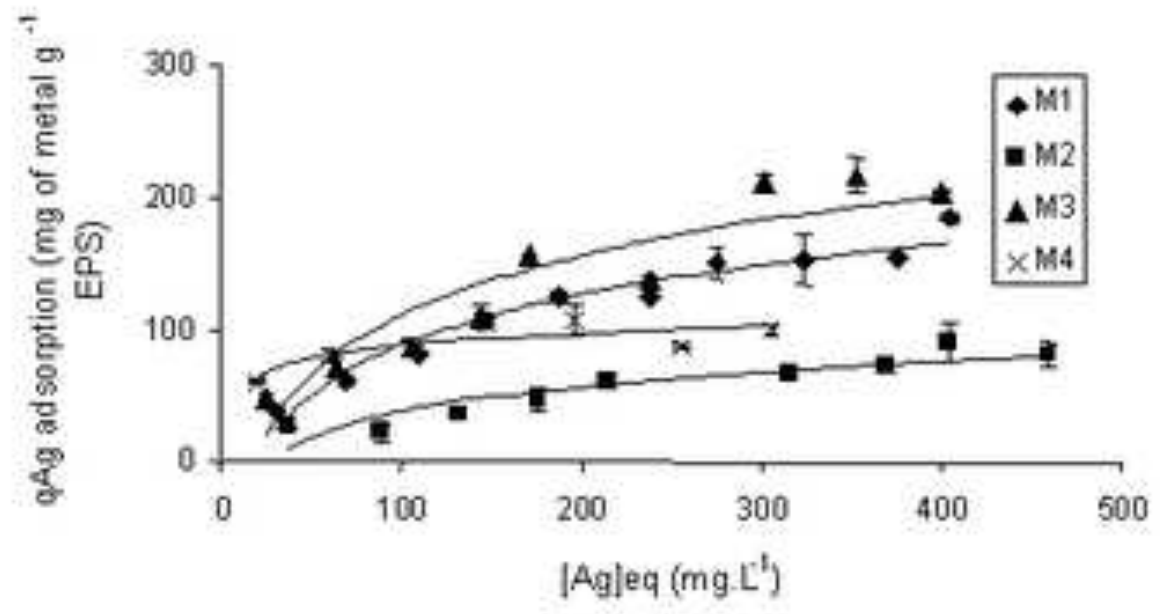


Click here to download high resolution image

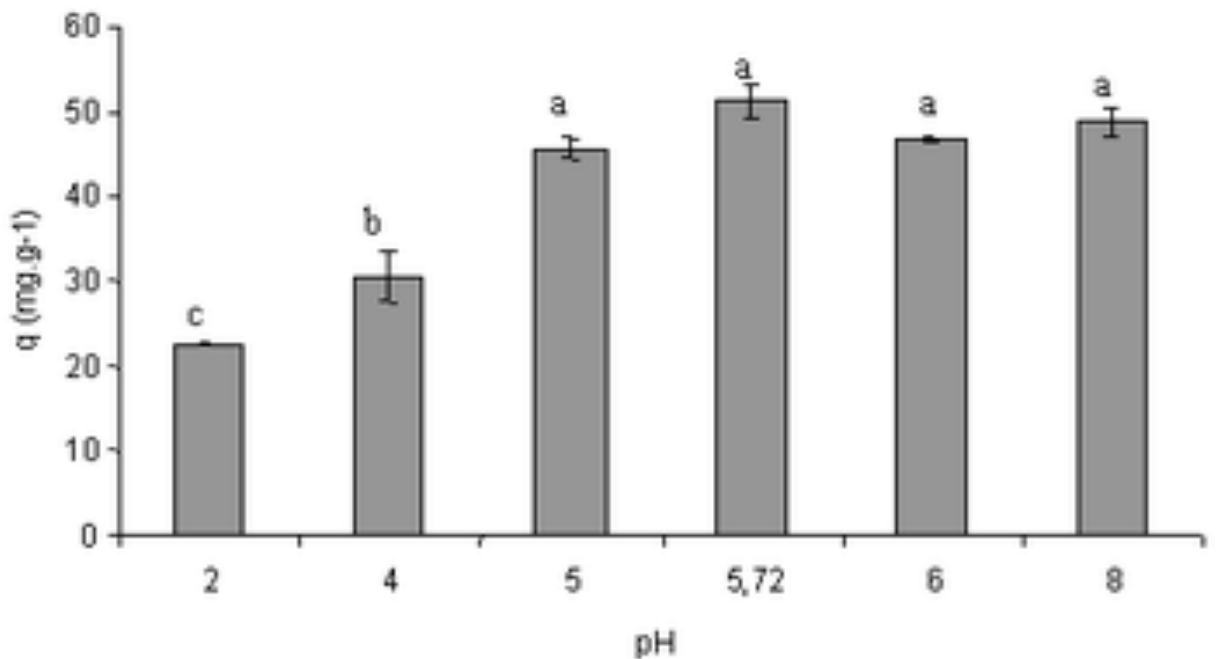


Click here to download high resolution image

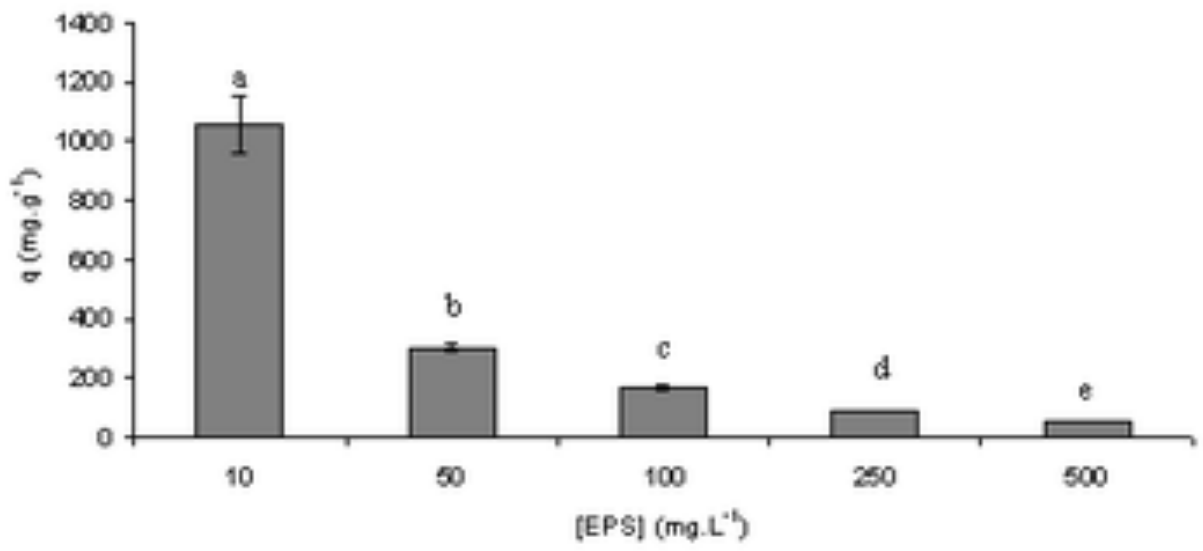




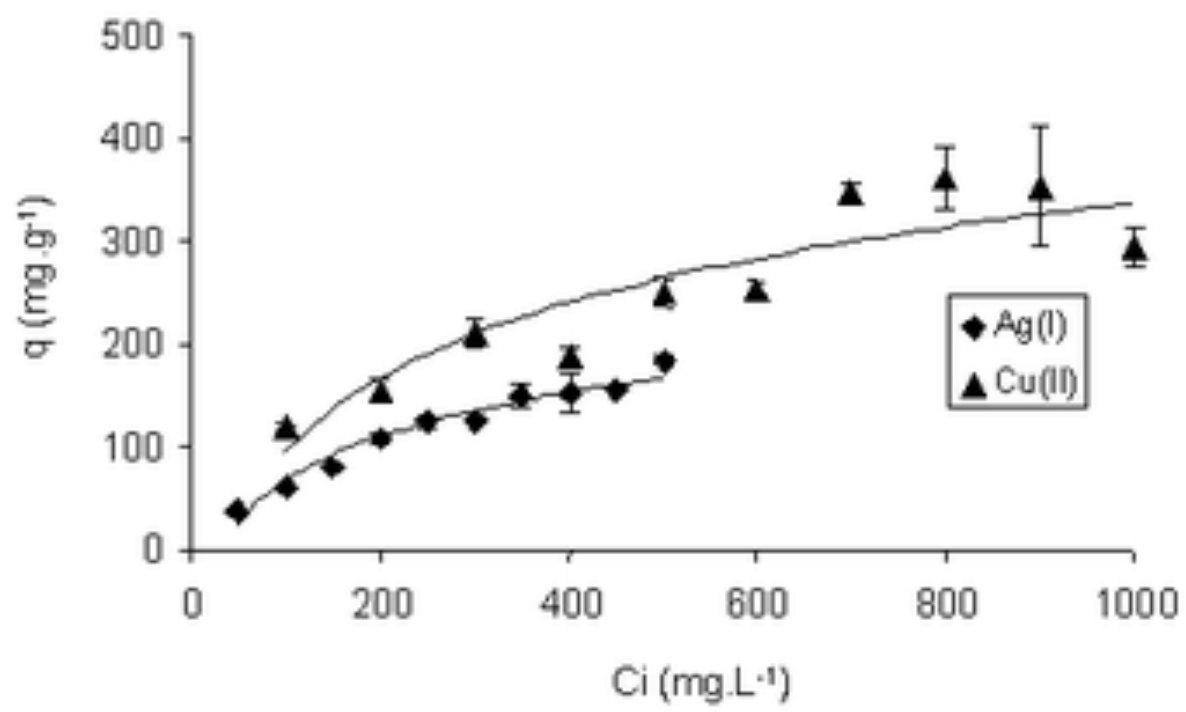


Click here to download high resolution image

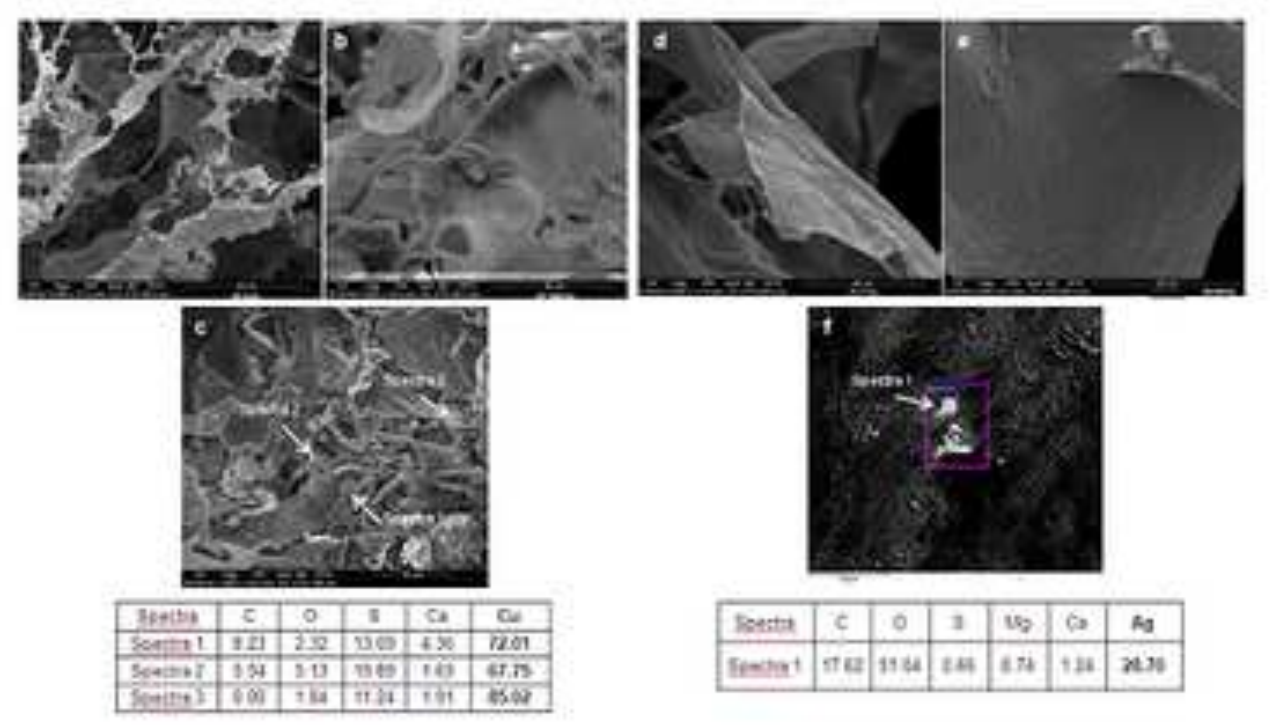


Figure 7
Click here to download high resolution image

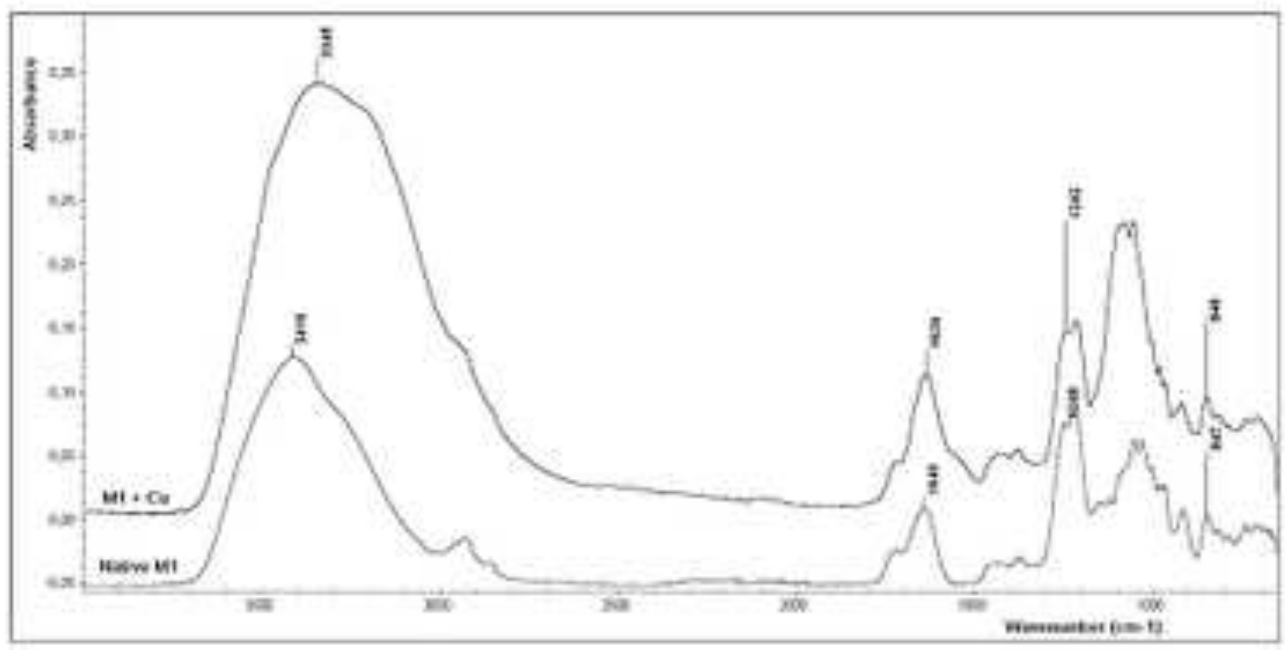

(1)

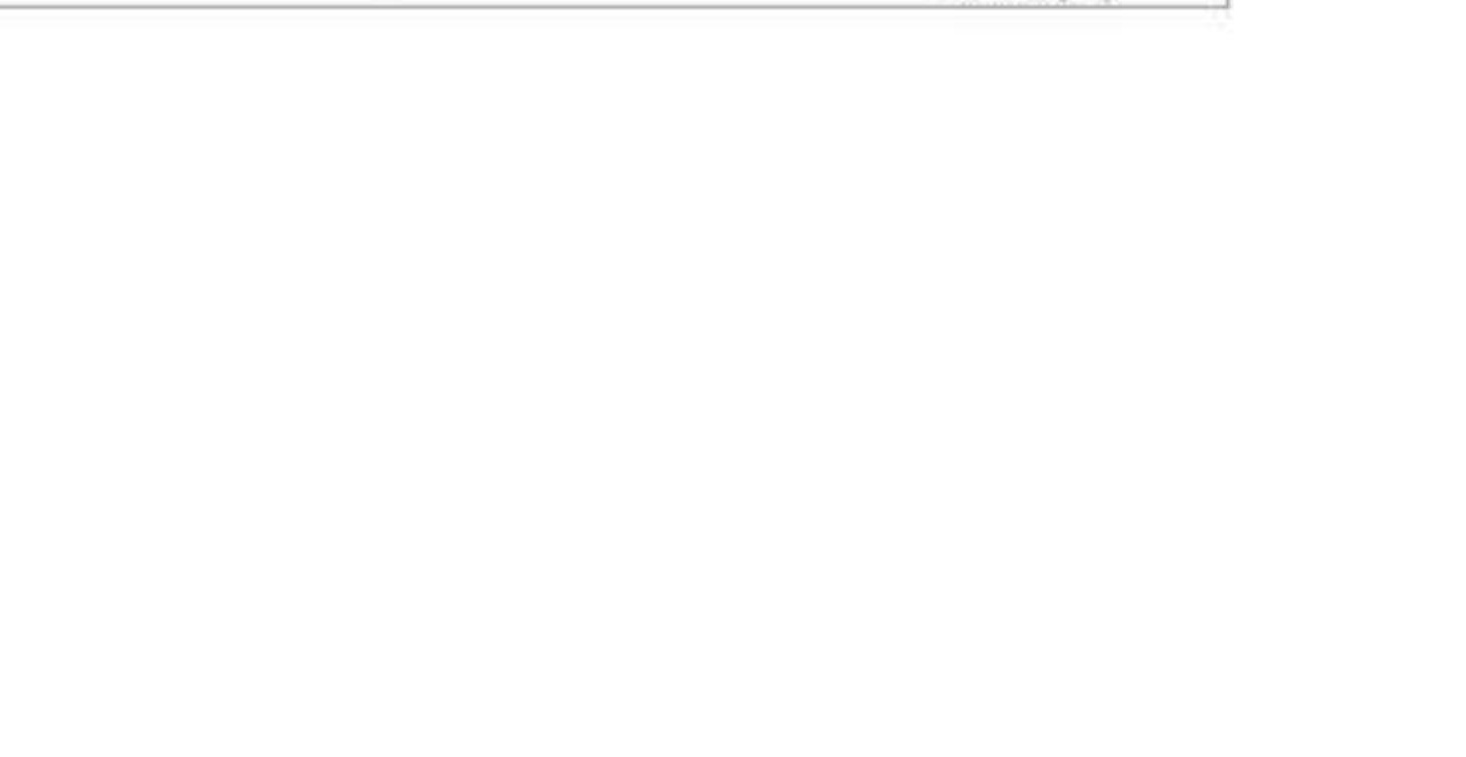

(

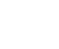

.

.

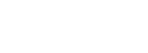

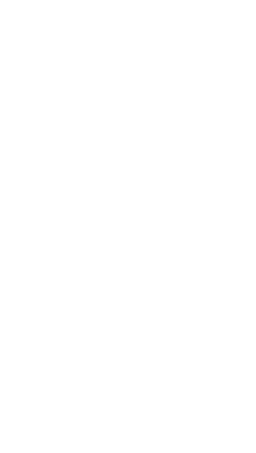
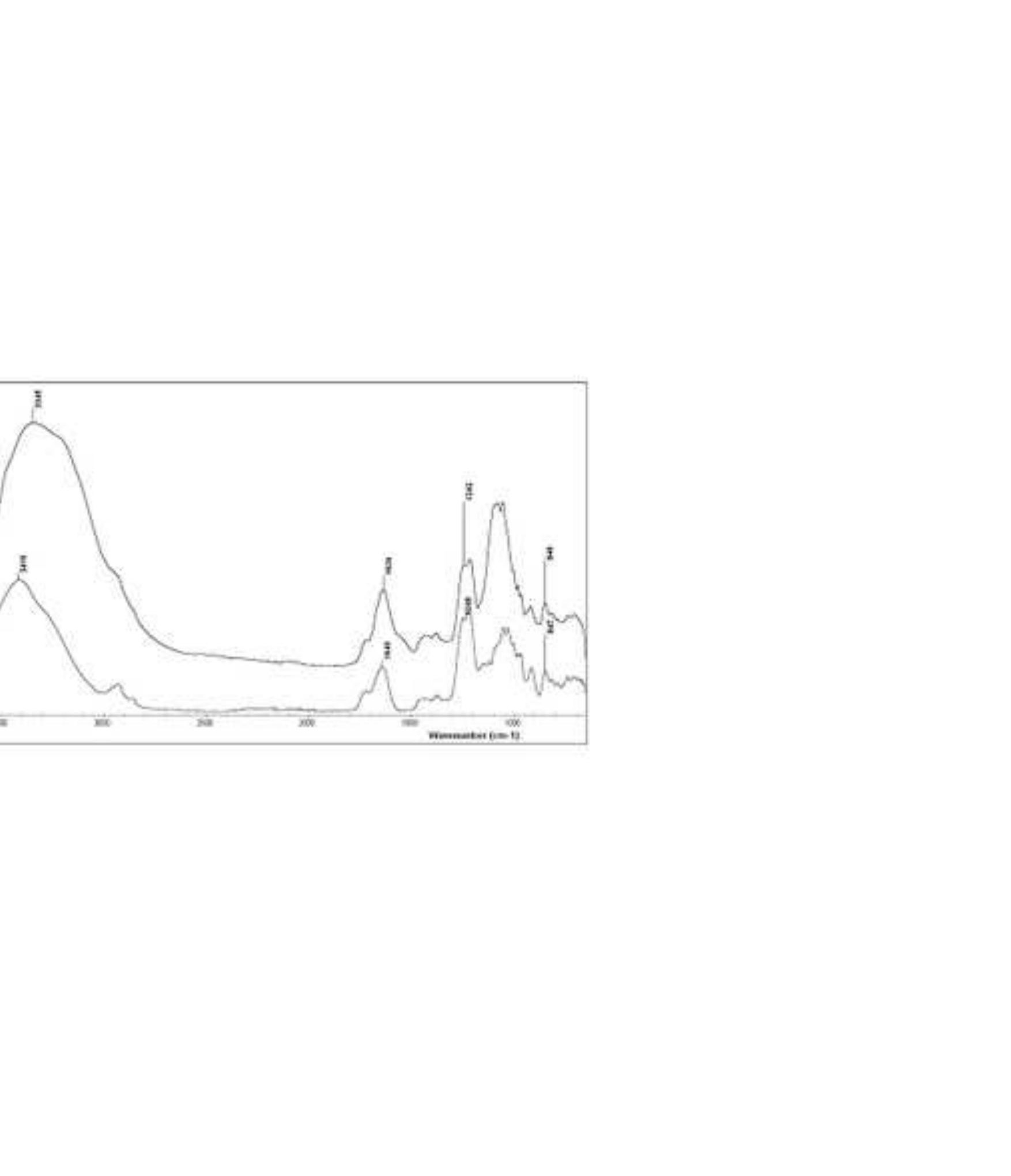
Figure 8
Click here to download high resolution image
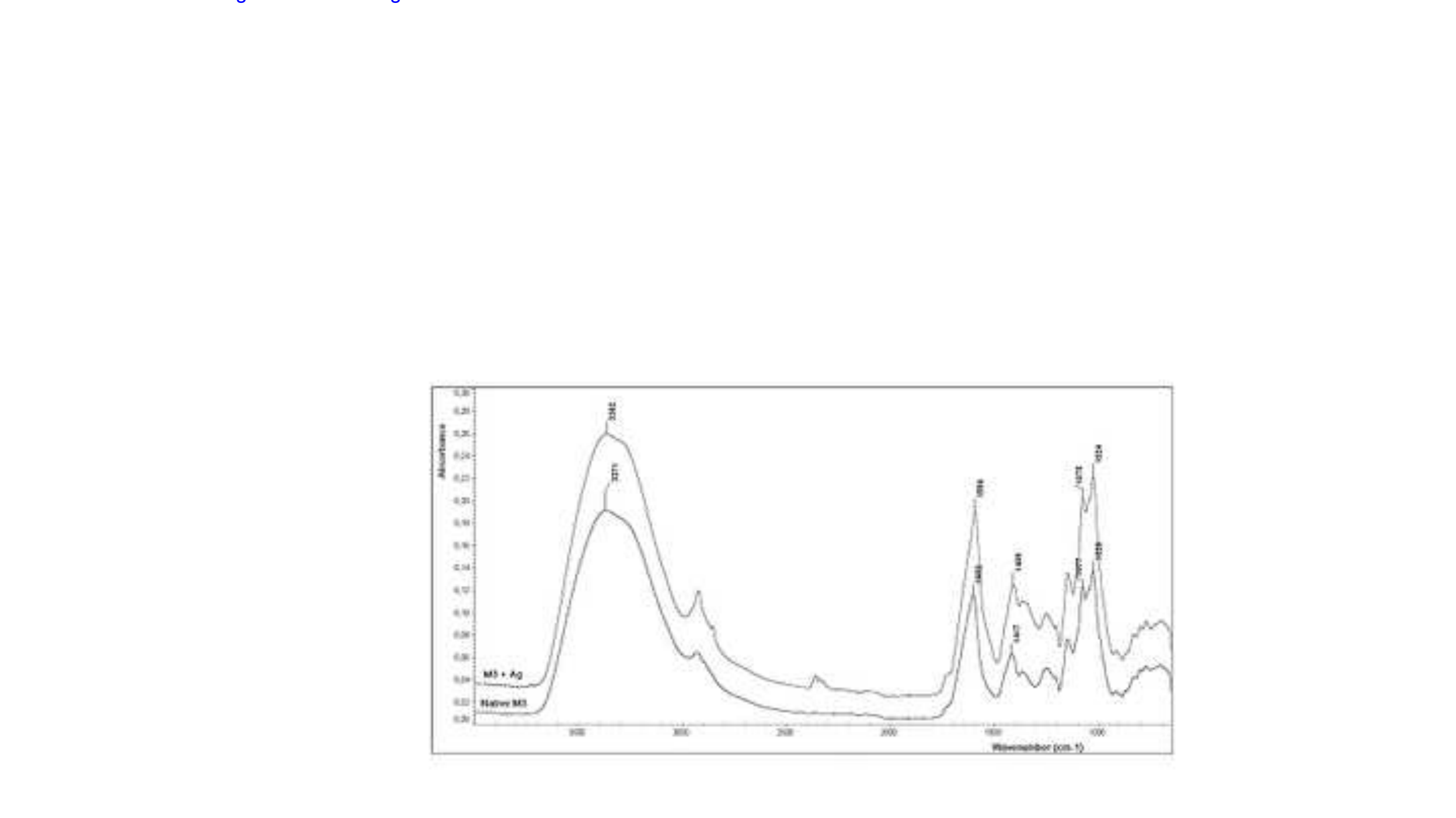$$
+\frac{1}{2}
$$
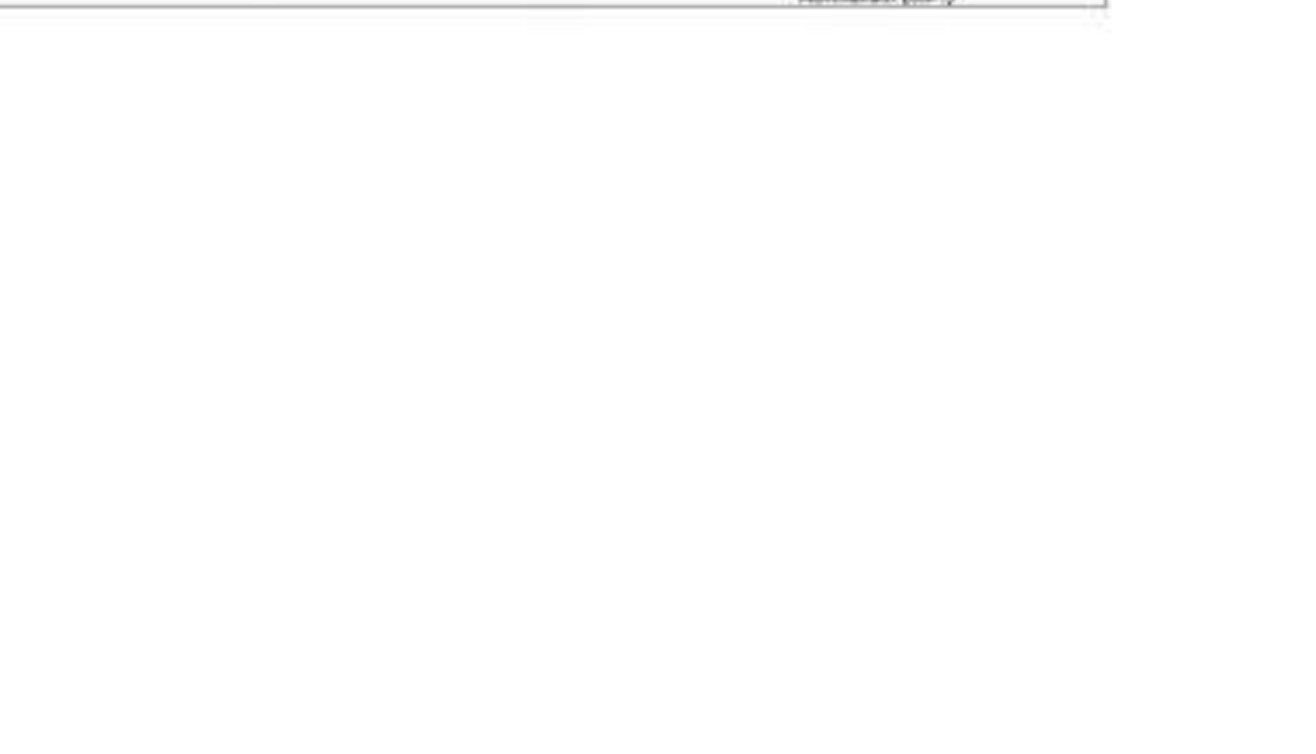

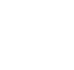




\begin{tabular}{|c|c|c|c|c|c|c|c|c|c|}
\hline EPS & Strains & $M w(k-0)]$ & b & $\begin{array}{c}\text { Proteirs } \\
\text { [\%] }\end{array}$ & $\begin{array}{l}\text { Nentral } \\
\text { sugast } \\
\text { (\%) }\end{array}$ & $\begin{array}{l}\text { Uronio } \\
\text { recids (36) }\end{array}$ & 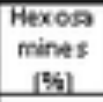 & $\begin{array}{c}\text { Sultotes } \\
\text { (\%/) }\end{array}$ & Suber tuents \\
\hline M1 & $\begin{array}{c}\text { Faracosous } \\
\text { pp. }\end{array}$ & 4300 & 1.3 & 3 & 48 & 8 & - & 29 & Acetate \\
\hline M2 & Uniblertithod & $8 \pi 0$ & 4.2 & 5 & 90 & treoces & - & - & - \\
\hline м3 & Abros on onas & 1800 & 2.6 & 4 & 46 & 20 & - & - & - \\
\hline M4 & Variosp. & 1300 & 2.2 & 2 & 11 & 27 & 30 & $=$ & Acetate \\
\hline
\end{tabular}




\section{Table 2}

Click here to download high resolution image

\begin{tabular}{|c|c|c|c|c|c|c|c|c|c|c|c|c|}
\hline \multirow[b]{3}{*}{ EPS } & \multicolumn{5}{|c|}{$\mathrm{Cu}(\mathrm{II})$} & & \multicolumn{6}{|c|}{$A g(I)$} \\
\hline & \multicolumn{2}{|c|}{$Q \max$} & \multicolumn{2}{|c|}{$K$} & \multirow[t]{2}{*}{$R^{2}$} & \multirow{2}{*}{$\frac{P \mathrm{G}^{\circ}}{\mathrm{kJ} / \mathrm{mor}^{1}}$} & \multicolumn{2}{|c|}{$Q \max$} & \multicolumn{2}{|c|}{$K$} & \multirow[t]{2}{*}{$R^{2}$} & \multirow{2}{*}{$\frac{P \mathrm{G}^{\circ}}{\mathrm{kJ} / \mathrm{mol}^{-1}}$} \\
\hline & $m g g^{-1}$ & $\mathrm{mmolg}^{-1}$ & $\mathrm{Lmg}^{-1}$ & $L m o f^{4}$ & & & $m g \cdot g^{-1}$ & $\mathrm{mmol}^{-1}$ & ${\mathrm{~L} . m g^{-1}}^{-1}$ & $L . m o r^{-1}$ & & \\
\hline M1 & 400 & 6.30 & 0,00537 & 341 & $0 . \varnothing 62$ & $-14,5$ & 256 & 2.38 & 0,00473 & 510 & 0.948 & $-15,5$ \\
\hline M2 & - & - & - & - & - & - & 145 & 1.34 & 0,00294 & 317 & 0.721 & $-14,3$ \\
\hline M3 & 139 & 1.29 & 0,0727 & 4614 & 0.965 & $.20,9$ & 333 & 3.09 & 0,00430 & 464 & 0.806 & $-15,2$ \\
\hline M4 & 112 & 1.77 & 0,0158 & 1003 & 0.960 & -17.1 & 100 & 0.930 & 0,109 & 11779 & 0.969 & $-23,2$ \\
\hline
\end{tabular}




\begin{tabular}{|c|c|c|c|c|c|c|c|}
\hline \multirow[t]{2}{*}{ Specie } & \multirow[t]{2}{*}{ Biosorbent } & \multicolumn{4}{|c|}{ Operating conditions } & \multirow[t]{2}{*}{$\begin{array}{r}\text { Omax } \\
\left(\mathbf{m g g}^{-1}\right) \\
\end{array}$} & \multirow[t]{2}{*}{ Reference } \\
\hline & & $\mathrm{pH}$ & $\begin{array}{c}\text { Biomass } \\
\left(g \cdot f^{-1}\right)\end{array}$ & $\mathrm{Co}\left(\mathrm{mg} . \mathrm{I}^{4}\right)$ & salts & & \\
\hline Paenibacilus polymyxa & EPS & 6 & 0,1 & 50 & sulfate & 1602 & $(30)$ \\
\hline Paenibacilus jamilae & EPS & 5,5 & 1 & $0,63-63,5$ & nitrate & 7.81 & (45) \\
\hline Zoogioea ramigera & polysaccharide & 5,5 & 0.83 & $0-500$ & n.a. & 323 & $(46)$ \\
\hline Bacifus timus & polysaccharide & 4 & 1 & $0-500$ & n.a. & 381 & $(47)$ \\
\hline Fucus vesiculus & brown algae & 5,5 & 2 & $5-50$ & nitrate & 23,4 & $(48)$ \\
\hline Sargassum sp. & brown algae & 4,5 & 2 & 500 & chloride & 110 & (49) \\
\hline Candide tropicalis & $\begin{array}{c}\text { yeast } \\
\text { sugarcane }\end{array}$ & 5,5 & n.a. & $0,6-65$ & n.a. & 80,0 & $(50)$ \\
\hline$?$ & bagasse & 5 & 0.5 & $100-1000$ & nitrate & 6.87 & $(20)$ \\
\hline M1. Paracoccus sp. & EPS & 5,9 & 0.5 & $100-1000$ & acetate & 400 & this study \\
\hline Clacosponism & & & & & & & \\
\hline cladosponaides & fungi & 4 & 2 & 100 & n.a. & 42,5 & (44) \\
\hline Asperginus niger & fungi & na. & 80 & 1000 & na. & 98.7 & $(51)$ \\
\hline $\begin{array}{l}\text { Calluna vulgaris } \\
\text { Saccharamyces }\end{array}$ & microalgae & 6,7 & 1,5 & $10-200$ & nitrate & 56,6 & (52) \\
\hline cerevisiae & yeast & 5,6 & 2 & 0,108 & nitrate & 41,8 & (35) \\
\hline Myxococcus xarthus & bacteria & 5.5 & 0,4 & $5.4-215$ & nitrate & 47,5 & $(21)$ \\
\hline Akaligenes eutrophus & EPS slime & 4 & n.a. & $1-1000$ & nitrate & 79,0 & $(53)$ \\
\hline M3, Alteromonas sp. & EPS & 5.7 & 0,5 & $50-500$ & nitrate & 333 & this study \\
\hline
\end{tabular}


Table 4

Click here to download high resolution image

\begin{tabular}{|c|c|c|c|c|c|c|c|c|c|c|c|c|}
\hline & \multicolumn{3}{|c|}{$\mathrm{pH} M 1$} & \multicolumn{3}{|c|}{$\mathrm{pH} M 2$} & \multicolumn{3}{|c|}{$\mathrm{pH} M 3$} & \multicolumn{3}{|c|}{$\mathrm{pH} M 4$} \\
\hline & arerage & s.d. & $\frac{n}{5}$ & average & s.d. & n & average & s.d. & n & $\begin{array}{c}\text { siverage } \\
555\end{array}$ & $\begin{array}{c}\text { sd } \\
025 ?\end{array}$ & $\begin{array}{l}n \\
6\end{array}$ \\
\hline $\begin{array}{l}\mathrm{Cu} \\
\mathrm{Aq}\end{array}$ & $\begin{array}{l}5,58 \\
6,46\end{array}$ & $\begin{array}{c}0,0907 \\
0,194\end{array}$ & $\begin{array}{l}5 \\
6\end{array}$ & $\begin{array}{l}5,54 \\
6,28\end{array}$ & $\begin{array}{l}0,275 \\
0,131\end{array}$ & $\begin{array}{l}6 \\
6 \\
\end{array}$ & $\begin{array}{l}5,61 \\
676\end{array}$ & $\begin{array}{l}0,165 \\
0,168\end{array}$ & $\begin{array}{l}5 \\
5\end{array}$ & $\begin{array}{l}5,56 \\
6,31\end{array}$ & $\begin{array}{l}0,252 \\
0,159\end{array}$ & $\begin{array}{l}6 \\
6\end{array}$ \\
\hline
\end{tabular}




\section{Figure and table legends}

Fig. 1 Equilibrium sorption isotherm of copper (100-1000 mg. $\left.\mathrm{L}^{-1}\right)$ by M1, M2, M3 and M4 EPS (EPS conc. : 0.5 g. $\left.\mathrm{L}^{-1} ; \mathrm{pH}=6.2\right)$. Error bars represent \pm standard deviation of triplicate samples.

Fig. 2 Equilibrium sorption isotherm of silver (50-500 mg. $\left.\mathrm{L}^{-1}\right)$ by M1, M2, M3 and M4 EPS (EPS conc. : 0.5 g.L $\left.\mathrm{L}^{-1} ; \mathrm{pH}=5.7\right)$. Error bars represent \pm standard deviation of triplicate samples.

Fig. 3 Effect of $\mathrm{pH}$ on silver $\left(50 \mathrm{mg} . \mathrm{L}^{-1}\right)$ sorption with M1 EPS (EPS conc. : 0.5g. $\left.\mathrm{L}^{-1}\right)$. Different letters indicate significant differences according to Tukey's test $(p<0.05)$. Error bars represent \pm standard deviation of triplicate samples.

Fig. 4 Effect of M1 EPS concentration on silver $\left(50 \mathrm{mg} . \mathrm{L}^{-1}\right)$ sorption. Different letters indicate significant differences according to Tukey's test $(p<0.05)$. Error bars represent \pm standard deviation of triplicate samples.

Fig. 5 Effect of initial $\mathrm{Cu}(\mathrm{II})$ and $\mathrm{Ag}(\mathrm{I})$ concentrations on sorption capacity (q) of EPS M1 (EPS conc. : 0.5g.L$\left.{ }^{1}\right)$. Error bars represent \pm standard deviation of triplicate samples.

Fig. 6 Scanning electron microscopy photography of a: native EPS M1; b: EPS M1+Cu; c: zoom and analysis of EPS M1 Cu; d: native EPS M3; e: EPS M3+Ag; $\mathrm{f}$ : zoom and analysis of EPS M3+Ag. White arrows indicate the area analysed by EDS. All values are in percentage by weight.

Fig. 7 FTIR spectra of EPS M1 before and after copper sorption.

Fig. 8 FTIR spectra of EPS M3 before and after silver sorption.

Table 1 Characteristics and chemical composition of the four studied exopolysaccharides (16.17).

Table 2 Langmuir parameters (Qmax and $\mathrm{K})$ and Gibbs free energy $\left(\Delta \mathrm{G}^{\circ}\right)$ for the sorption of $\mathrm{Cu}$ and $\mathrm{Ag}$ on four EPS and the correlation coefficient $\left(\mathrm{R}^{2}\right)$.

Table 3 Comparison of copper and silver uptake capacities (Qmax, mg.g ${ }^{-1}$ ) and operating conditions of various natural biosorbents. n.a : not available.

Table $4 \mathrm{pH}$ values of EPS ofr $\mathrm{Cu}(\mathrm{II})$ and $\mathrm{Ag}(\mathrm{I})$ during metal sorption. s.d. : standard deviation ; $\mathrm{n}$ : number of values. 